\title{
Rhetoric and Reality: A Case Study of a Course in English for Specific Purposes
}

\author{
Abdel Halim Sykes \\ Teaching and Learning Centre, SIM University \\ 461 Clementi Road, Singapore, 599491 \\ E-mail: abdelhalim@unisim.edu.sg
}

Received: August 15, 2014 Accepted: August 22, $2014 \quad$ Published: August 22, 2014

doi:10.5296/ijele.v2i2.6189 URL: http://dx.doi.org/10.5296/ijele.v2i2.6189

\begin{abstract}
This paper explores how far a course in English for Specific Purposes (ESP) adheres to the notions of ESP course preparation, design and delivery found in the literature. The research followed the planning, design, development and delivery of the course over a one-month period. Data were gathered through observations and interviews with relevant stakeholders in the course. The findings show that in the absence of an adequate needs analysis and very limited preparation time, the course developers used their knowledge and experience to develop, design and deliver the course by anticipating the most likely needs of the learners and the learning outcomes associated with those perceived needs. While the developers of the course were unable to formulate a detailed pre-course needs analysis and had little time to develop the course, they were able to make the course more specific to the needs of their learners as it progressed. The conclusion is that even without an initial detailed needs analysis and clearly defined learning outcomes, it is possible through knowledge, experience and adaptability for course developers and teachers to deliver courses that can be categorized as ESP.
\end{abstract}

Keywords: English for Specific Purposes, needs analysis, course design, course delivery 


\section{Introduction}

The purpose of this paper is to analyze and describe an English language course in light of the theories underpinning the notion of ESP. It seeks to establish the extent to which the course matches the description of an ESP course presented in the literature. Firstly, an overview of relevant literature will be presented with reference to (1) needs analysis, (2) materials and (3) evaluation. Secondly, a discussion of the course will be given in light of the issues raised in the literature. Thirdly, conclusions will be drawn to assess the degree to which the rhetoric on ESP is affirmed by the reality of the course in question.

\section{The Rhetoric}

\subsection{Defining ESP}

Before proceeding, it is necessary to clarify what is meant by the term 'English for Specific Purposes' as it is discussed in this paper. ESP courses are 'specific' in that priority is given to determining the needs of the learners and all efforts are made in the attempt to meet those needs (Dudley-Evans and St. John, 1998). The 'purpose' which courses seek to fulfill refers to the relevance and practical use of the language being taught in order for learners to function effectively in their chosen fields (Widdowson, 1983; Cook, 2002). Therefore, ESP requires the development of courses in which there are clearly identified reasons for learning (Hutchinson and Waters, 1987; Barnard and Zemach, 2003) and in which opportunities for real-world use of the newly acquired language skills is apparent and is clearly recognizable as the learning objective (Widdowson, 1983; Cook, 2002; Basturkmen, 2010).

\subsection{Needs Analysis in ESP}

Dudley-Evans and St. John (1998) provide a succinct definition of needs analysis in ESP as 'the process of establishing the what and how of a course' (p.121). As such, the primary function of needs analysis is to gather data which can be used to identify the specific English language needs of learners. In ESP, learners' needs are typically thought of in terms of performance, that is, what the learners will be able to do, and continue to do with the language they have acquired once the course is completed (Richards, 2001; Cook, 2002). If all the stakeholders in the course, i.e., sponsors, learners and teachers, have a clear understanding of why the learners need English, that knowledge will determine the specific content of the course (Hutchinson and Waters, 1987). Once the essential target situations of the course have been identified, it becomes the responsibility of course designers and teachers to create and conduct courses that are suitable for their learners (Johns and Dudley-Evans, 1991; Hyland, 2008).

Prior to undertaking a needs analysis, consideration should be given to the following factors: (1) the amount of time available to collect and process data, (2) who will participate in the needs analysis, (3) who will be responsible for preparing and conducting the needs analysis, and (4) how the data is going to be analyzed and the information used (Robinson, 1991). Richards (2001) suggests that a triangular approach to gathering relevant information should be taken; that is, the needs analysis should consist of information gathered in a variety of ways from a range of sources. This, he argues, would ensure that there is a reduced risk that 
the data may be partial or incomplete rather than if taken from a single source and gathered using only one method. Given adequate time and sufficient resources, questionnaires, self-ratings, interviews, observations and meetings all have a significant role to play in establishing the specific needs of language learners. The needs of learners can also be established by directing questions at sponsors or those working in the target situation.

Robinson (1991) makes a distinction between a present situation analysis (PSA) and a target situation analysis (TSA). The purpose of the PSA is to identify the level and skills of the learners. Other factors of importance with this analysis are the timing, facilities and venue of the course, as well as the experience of the proposed teachers of the course. The TSA is conducted with the aim of establishing the needs of the learners at the end of the language course: what skills and competencies they should have acquired. In addition to establishing PSA and TSA, Hyland (2008) suggests needs analysis 'involves decisions based on teachers' interests, values, and beliefs about teaching, learning and language' (p.113); thus, bringing both learners and teachers into the needs analysis mix.

However data is gathered, it is essential for it to be accurate and relevant in order to enable course designers and teachers to prepare a course suitably specific to the needs of the learners. It is also important for those designing ESP courses to be aware of the possibility that the nature of the learners' needs may change as they progress through the course (West, 1994). This awareness can be informed by the undertaking of periodic formative evaluations (Dudley-Evans and St. John, 1998) in order to ensure that the course remains truly specific to the needs of the learners. Moreover, to ensure specificity, ongoing revision of the course might be necessary (Basturkmen, 2010).

\subsection{Materials for ESP}

Once needs have been established, course objectives and learning outcomes can be identified. These objectives and outcomes will be the specific changes a course seeks to bring about (Richards, 2001). They should be (1) precise, (2) feasible and (3) describe an achievable learning outcome. Suitable materials and activities for a particular group of learners within a specific learning context (Johns and Dudley-Evans, 1991), which will reflect the course objectives, can now be selected or created. The ESP course should be designed in such a way as to maximize the full potential of the learning context (Hutchinson and Waters, 1987); that is, designers and teachers should adopt a learning-centered approach.

Despite the necessary specificity of the ESP course, those involved in the design and development of the course should not derive its linguistic input from a single or narrow source (Hutchinson and Waters, 1987). Nor should it necessarily involve the creation of brand new, wholly original material if suitable or adaptable resources can be found. Swales (1980) suggests that 'it would be useful to consider the potential virtues to be found in published materials. One such virtue is that they have a clearly discernible shape: a beginning, a middle and an end' (p.18). By being aware of existing materials and evaluating their suitability, course designers will be able to utilize a wide range of resources which could provide all or part of the materials needed for the ESP course without having to duplicate work previously carried out in the specific field (Hutchinson and Waters, 1987). The point is that the ESP 
course does need to be specific, but it need not be wholly original.

In addition to having content specific to the needs of the learners and the objectives of the course, materials should have a clear and coherent structure. This structure will enable both learners and teachers to navigate effectively through the range of activities presented so as to maximize learning opportunities (Hutchinson and Waters, 1987). Providing an overall shape to the course creates predictability for the learner and thus gives 'some assurance of where he is going, how far he has gone, and how far he still has to go' (Swales 1980, p.18).

To meet the specific needs of the learners, course designers may utilize various approaches, since in meeting the ESP challenge they might need to combine a number of different strategies in an eclectic manner to achieve the desired objectives (Dubin and Olshtain, 1986). By doing this, course designers and teachers take into consideration that fact that not all learners learn in the same way, even if their learning objectives are the same. Course designers who provide interesting and attractive materials and activities that help learners to learn in addition to meeting their specific and immediate objectives also provide learners with the framework upon which to develop their language skills long after the course has finished. To this end, Harding (2007) suggests exploiting authentic materials and using real or simulated texts and contexts that involve the specific language and functions learners need in their work beyond the language classroom.

\subsection{Evaluation in ESP Courses}

It has been suggested that 'the origins of ESP lie in satisfying needs' (Hutchinson and Waters, 1987, p.152). After identifying needs at the initial stages of the ESP process and addressing those needs through the delivery of appropriate material, it is axiomatic that an evaluation should be conducted to ascertain the extent to which those needs are being or have been met. The purpose of evaluation is to provide feedback to inform, in particular, learners, teachers and course designers, but also other stakeholders such as sponsors, about whether objectives have been met and about any new needs which may have become apparent during the course. This feedback might provide important input to the content, materials and methods for the remainder of the course and for future courses (Hutchinson and Waters, 1987; Basturkmen, 2010). Evaluation might focus on seeking different kinds of feedback on a variety of aspects of the course and of the learning at different times. Formative evaluation may be undertaken at regular intervals to enable teachers and course designers to adapt and fine-tune the course further to meet the needs of the learners.

\section{The Reality}

\subsection{Defining the Specific Purpose}

The title of the course this study analyzes and describes is 'A course in English for International Communication'. No mention is made in the title of the field or area of interest of the learners that could give some indication of the specific requirements of the learners. Thus, there is no indication of who the intended participants are. Similarly, no specifics are given to show learners and sponsors which skills are to be taught and developed. Moreover, 'International Communication' would appear to be a catchall term since no reference is made 
to the specific communicative function to which learners would apply their English language skills. Without these specifics, the detailed purpose of the course is unclear to the learners, the teachers and the sponsors: having no clearly defined nor recognizable learning objectives. Therefore, the course title fails to provide the essential information necessary to identify the specific purpose of the course, i.e., the type of course, who it is for, the skills to be taught and the communicative use to which those skills will be put. This lack of specificity in the title presents problems at different levels for (1) learners, (2) designers and (3) teachers of the course in that it provides no indication of the focus or content of the course.

\subsection{Attempting to Analyze Needs}

To conduct a successful needs analysis, course designers must secure access to information on the prospective participants of a course. Ideally, this would involve direct contact with the learners or, where this is not possible, communication with sponsors and those in the field from which the learners will be drawn. Much of the literature assumes that there is sufficient time and resources to conduct a needs analysis prior to the start of the course. However, the designers of 'A course in English for International Communication' were not in such an ideal situation. No contact was possible between the learners and designers, and all information in both directions was conducted via the sponsors. In spite of pressing the sponsors for the details necessary for designing a course which could address the specific purposes of the learners, the sponsors provided only the name, professional position and highest educational qualification of each of the participants, all of whom were local government officials from one province in China. This information was received less than one week before the commencement of the course, and after materials had been designed. Perhaps the sponsors failed to realize the significance of the information the course designers had requested because this was their first experience of funding a language training course. As far as the sponsors were concerned, the purpose in funding the course was to improve their standing with the provincial government from which the participants came for the advancement of their own commercial interests. This reason may also explain the sponsors' reluctance (due to extra costs) to divide the learners into two groups, as requested by the course designers on receiving the learners' profiles. If the main motive of the course was to provide an appropriate and meaningful ESP course, then the sponsors and the learners would have welcomed the benefits that grouping the learners might have brought. However, the sponsors' commercial considerations outweighed the need to provide a truly specific and tailored course.

Since time was short, information scant and sponsors' input negligible, the course designers were required to make assumptions about the possible needs of the prospective learners and the specific purposes of the course. These assumptions were based on past experiences with similar learners from other government agencies in China. The needs analysis on this course, therefore, became a matter of identifying elements of an assumed target situation which depended on the designers' own intuitions about what the learners would most probably need. These intuitions were based on approximately five years' experience each of the course designers had in teaching ESP courses to government official from China. Thus, the needs analysis was a subjective process informed by the barest information about the learners and 
their assumed needs. In essence, the what of the course was not established, and the how was based on experience: illustrating clearly, in this case, that 'needs analysis is a political and subjective process' (Benesch 1996, p.736).

Although a complete forty-hour course was designed, hard copies of material were prepared only for the first two teaching sessions. The remainder was saved as soft copies to facilitate any adaptations perceived by the teachers to be necessary upon meeting the learners and assessing their needs. Consequently, although the content of the course was little changed, the teaching approach was determined by the outcome of the first day's sessions and the decisions made at the daily post-session meetings held between the teachers on the course. Thus, to some extent, the course was still under development as it was being delivered. Only when contact with the learners was made, the teaching staff could attempt to adapt the prepared materials to suit the needs, learning styles and abilities of the course participants.

\subsection{Preparing Materials}

Two of the three teaching staff assigned to the course were involved in developing the course materials. Due to the lack of information on the learners and a relatively short lead-in time of two weeks, it was decided to use materials which had previously been used for other courses for Chinese government officials by the same course provider. Several general areas of interest were identified, and suitable, tried and tested methods were selected based on previous experience with learners similar to those who were expected to participate on the new course.

The structure of the course followed the format used for almost all courses conducted by the course provider, i.e., Vocabulary, Listening and Speaking, and Presentation Skills. Each teacher was given responsibility for teaching a specific component. This structure allowed for easy scheduling of the teaching staff and allowed learners to understand the focus of the lesson at hand. This approach proved useful in situ since several of the participants were unable to attend every session. The fact that each lesson was a self-contained unit meant that those who were absent from a previous session were not disadvantaged in the succeeding sessions.

In order to attempt to specify the purpose of the course, a brief introduction was presented to the learners upon commencement of the course. This statement was prepared prior to direct contact with the learners and served as a substitute for a definitive statement on more specific goals. These general goals represented the beliefs and attitudes of the teachers and designers of the course (Dubin and Olshtain, 1986) in the absence of a clearly defined needs analysis. It also provided a rationale for the content of the course and allowed for any necessary adaptation in terms of specific needs and methods. During the course, the teachers were able to adapt the basic materials to better meet the needs of the course participants. These adaptations were based on feedback via informal comments made by learners and on observations made by the teaching staff. Thus, the course became more specific once the teachers had made contact with the learners. 


\subsection{Evaluating the Course}

At the end of the course, an evaluation form was completed by each learner. The form followed the standard end-of-course evaluation used for all courses by the course provider. It was decided this form should be written in both English and Chinese in order to encourage learners to express themselves fully and with ease. However, only one of the twenty respondents chose to provide written feedback in Chinese.

The problem with analyzing the feedback was that there had been no needs analysis. As such, it was impossible to evaluate whether the specific needs of the learners had been met. Feedback regarding the performance of the teaching staff was straightforward and easy to pass judgment on, but feedback on meeting the needs of the learners was almost impossible to judge due to the disparate and wide-ranging fields and interests of the learners and the lack of a TSA.

\section{Conclusion}

While it is undoubtedly an advantage to course designers to have as much information as possible about the learners, their learning needs and their target needs, in reality, as illustrated by the course in question, it is not always readily available nor easily acquired. Course designers are dependent on the ability and the goodwill of other stakeholders in the pursuit of information necessary for the planning of English language courses which are truly specific to a given purpose. As such, course designers and teachers often must use their intuition, experience and knowledge to ascertain the perceived specifics and purpose of a course. The pressure of time, sponsors, management, and, not least, the desire to provide a meaningful and fruitful course for the learners are factors which cause the course designers to make assumptions and, in effect, decide the specific purposes of the course in the absence of any substantial information on learners, a PSA or a TSA.

The purposes of 'A course in English for International Communication' as defined by the course designers were (1) to allow learners to practise their existing English language skills and (2) to develop those skills further to enable them to communicate competently and confidently in a number of situations. These purposes were intentionally non-specific since to produce a set of specifics without adequate knowledge of needs would have meant designing a course which would probably not have met the learners' needs. By identifying a purpose and attempting to adapt the materials to specifics during delivery of the course, the course designers intended to offer a structure within which specifics could be catered as the course was being conducted.

More often than not, as this study shows, course designers cannot and should not be wholly depended upon a needs analysis to determine the specific purpose of an ESP course. With or without a needs analysis, judgment calls about the nature, structure and purposes of a course are essentially made by course developers and teachers. Therefore, while the course in question did not adhere absolutely to the descriptions of ESP courses to be found in the literature (like many other courses), it can be categorized as an ESP course in that, although initially it lacked specifics, it did have an identifiable general purpose and the course 
developers and teachers were able to adapt the materials while the course was on-going to meet some of the specific needs of the learners. If the learners on 'A course in English for International Communication' continue to use what they learned and use the course as a platform from which to develop their skills further according to their own specific purposes, then the course would have been successful. However, only by conducting some form of assessment of post-course performance could this be shown; as is the case with all ESP courses.

In conclusion, this study shows ESP professionals cannot always rely on the provision of information required for a detailed needs analysis and do not always have the advantage of a long period of course development. Nevertheless, they are able, through knowledge, experience and adaptability, to provide courses that do go some way in meeting the specific English language needs of their learners. Finally, it could be argued that this course, and the way it was conducted, is closer to the reality of ESP teaching on the ground rather than adhering closely to the idealized notions of ESP found in the literature.

\section{References}

Barnard, R., \& Zemach, D. (2003). Materials for Specific Purposes. In B. Tomlinson (ed.), Developing Materials for Language Teaching. London: Continuum.

Basturkmen, H. (2010). Developing Courses in English for Specific Purposes, Basingstoke: Palgrave Macmillan. http://dx.doi.org/10.1057/9780230290518

Benesch, S. (1996). Needs Analysis and Curriculum Development in EAP: An Example of a Critical Approach, TESOL Quarterly, 30/4: 723-738. http://dx.doi.org/10.2307/3587931

Cook, V. (2002). Language Teaching Methodology and the L2 User Perspective. In V. Cook (ed.), Portraits of the L2 User. Clevedon: Multilingual Matters.

Dubin, F., \& Olshtain, E. (1986). Course Design. Cambridge: Cambridge University Press

Dudley-Evans, T., \& St. John, M.J. (1998). Developments in English for Specific Purposes. Cambridge: Cambridge University Press.

Harding, K. (2007). English for Specific Purposes, Oxford: Oxford University Press.

Hutchinson, T. \& Waters, A. (1987). English for Specific Purposes. Cambridge: Cambridge University Press. http://dx.doi.org/10.1017/CBO9780511733031

Hyland, K. (2008). The Author Replies, TESOL Quarterly, 42: 113-114.

Johns, A. M., \& Dudley-Evans, T. (1991). English for Specific Purposes: International in Scope, Specific in Purpose. TESOL Quarterly, 25/2: 297-313. http://dx.doi.org/10.2307/3587465

Richards, J. C. (2001). Curriculum Development in Language Teaching. Cambridge: Cambridge University Press. http://dx.doi.org/10.1017/CBO9780511667220

Robinson, P. C. (1991). ESP Today: A Practitioner's Guide. Oxford: Prentice Hall.

Swales, A. (1980). ESP: The Textbook Problem. ESP, 1/1: 11-23. 
Widdowson, H. G. (1983). Learning Purpose and Language Use. Oxford: Oxford University Press.

West, R. (1994). Needs analysis in language teaching, Language Teaching, 27/1: 1-19. http://dx.doi.org/10.1017/S0261444800007527

\section{Copyright Disclaimer}

Copyright for this article is retained by the author(s), with first publication rights granted to the journal.

This is an open-access article distributed under the terms and conditions of the Creative Commons Attribution license (http://creativecommons.org/licenses/by/3.0/). 